\title{
Front Matter: Volume 10180
}

, "Front Matter: Volume 10180," Proc. SPIE 10180, Tri-Technology Device Refrigeration (TTDR) II, 1018001 (27 June 2017); doi: 10.1117/12.2280580

SPIE. Event: SPIE Defense + Security, 2017, Anaheim, CA, United States 


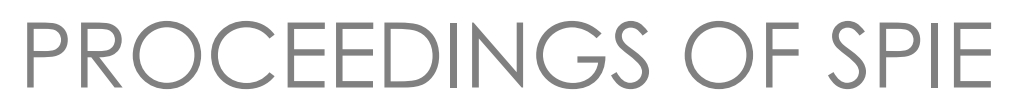

\title{
Tri-Technology Device Refrigeration (TTDR) II
}

\author{
Richard I. Epstein \\ Bjørn F. Andresen \\ Tonny Benschop \\ Joseph P. Heremans \\ Sergey V. Riabzev \\ Mansoor Sheik-Bahae \\ Editors
}

11 April 2017

Anaheim, California, United States

Sponsored and Published by

SPIE 
The papers in this volume were part of the technical conference cited on the cover and title page. Papers were selected and subject to review by the editors and conference program committee. Some conference presentations may not be available for publication. Additional papers and presentation recordings may be available online in the SPIE Digital Library at SPIEDigitallibrary.org.

The papers reflect the work and thoughts of the authors and are published herein as submitted. The publisher is not responsible for the validity of the information or for any outcomes resulting from reliance thereon.

Please use the following format to cite material from these proceedings:

Author(s), "Title of Paper," in Tri-Technology Device Refrigeration (TTDR) II, edited by Richard I. Epstein, Bjørn F. Andresen, Tonny Benschop, Joseph P. Heremans, Sergey V. Riabzev, Mansoor Sheik-Bahae, Proceedings of SPIE Vol. 10180 (SPIE, Bellingham, WA, 2017) Seven-digit Article CID Number.

ISSN: 0277-786X

ISSN: 1996-756X (electronic)

ISBN: 9781510608610

ISBN: 9781510608627 (electronic)

Published by

SPIE

P.O. Box 10, Bellingham, Washington 98227-0010 USA

Telephone +1 3606763290 (Pacific Time) · Fax +1 3606471445

SPIE.org

Copyright (@) 2017, Society of Photo-Optical Instrumentation Engineers.

Copying of material in this book for internal or personal use, or for the internal or personal use of specific clients, beyond the fair use provisions granted by the U.S. Copyright Law is authorized by SPIE subject to payment of copying fees. The Transactional Reporting Service base fee for this volume is $\$ 18.00$ per article (or portion thereof), which should be paid directly to the Copyright Clearance Center (CCC), 222 Rosewood Drive, Danvers, MA 01923. Payment may also be made electronically through CCC Online at copyright.com. Other copying for republication, resale, advertising or promotion, or any form of systematic or multiple reproduction of any material in this book is prohibited except with permission in writing from the publisher. The CCC fee code is $0277-786 \mathrm{X} / 17 / \$ 18.00$.

Printed in the United States of America.

Publication of record for individual papers is online in the SPIE Digital Library.

\section{SPIE. DIGITAL \\ SPIEDigitallibrary.org}

Paper Numbering: Proceedings of SPIE follow an e-First publication model. A unique citation identifier (CID) number is assigned to each article at the time of publication. Utilization of CIDs allows articles to be fully citable as soon as they are published online, and connects the same identifier to all online and print versions of the publication. SPIE uses a seven-digit CID article numbering system structured as follows:

- The first five digits correspond to the SPIE volume number.

- The last two digits indicate publication order within the volume using a Base 36 numbering system employing both numerals and letters. These two-number sets start with 00, 01, 02, 03, 04, 05, 06, 07, 08, 09, OA, OB ... 0Z, followed by 10-1Z, 20-2Z, etc. The CID Number appears on each page of the manuscript. 


\title{
Contents
}

\author{
$\checkmark$ Authors \\ vii Conference Committee
}

MECHANICAL COOLERS: MINIATURIZATION

1018002 Development of a miniature Stirling cryocooler for LWIR small satellite applications (Invited Paper) [10180-1]

1018003 A miniature pulse tube cryocooler used in a superspectral imager (Invited Paper) [10180-2]

1018004 Lockheed Martin microcryocoolers (Invited Paper) [10180-3]

1018005 RICOR Cryocoolers for HOT IR detectors from development to optimization for industrialized production (Invited Paper) [10180-4]

1018006 Ceramic 3D printed Joule Thomson mini cryocooler intended for HOT IR detectors (Invited Paper) [10180-5]

1018008 RMs 1: qualification results of the rotary miniature Stirling cryocooler at Thales Cryogenics (Invited Paper) [10180-7]

\section{EMERGING TECHNOLOGIES II}

10180 OC Forward to cryogenic temperature: laser cooling of Yb: LuLiF crystal (Invited Paper) [10180-11]

MECHANICAL COOLERS: DESIGN ISSUES

10180 OD Tactical versus space cryocoolers: a comparision [10180-12]

10180 OE Ricor's anniversary of 50 innovative years in cryogenic technology [10180-13]

10180 OF Attenuation of cryocooler induced vibration using multimodal tuned dynamic absorbers [10180-22]

10180 OG RICOR K527 highly reliable linear cooler: applications and model overview [10180-16] 
MECHANICAL COOLERS: VARIOUS

$10180 \mathrm{Ol} \quad$ How to manage MTTF larger than $30,000 \mathrm{hr}$ on rotary cryocoolers [10180-18]

10180 OK Ricor's Nanostar water vapor compact cryopump: applications and model overview [10180-20]

$10180 \mathrm{OL} \quad$ Performance, optimization, and latest development of the SRI family of rotary cryocoolers [10180-21] 


\section{Authors}

Numbers in the index correspond to the last two digits of the seven-digit citation identifier (CID) article numbering system used in Proceedings of SPIE. The first five digits reflect the volume number. Base 36 numbering is employed for the last two digits and indicates the order of articles within the volume. Numbers start with $00,01,02,03,04,05,06,07,08,09,0 A, 0 B . .0 Z$, followed by 10-1Z, 20-2Z, etc.

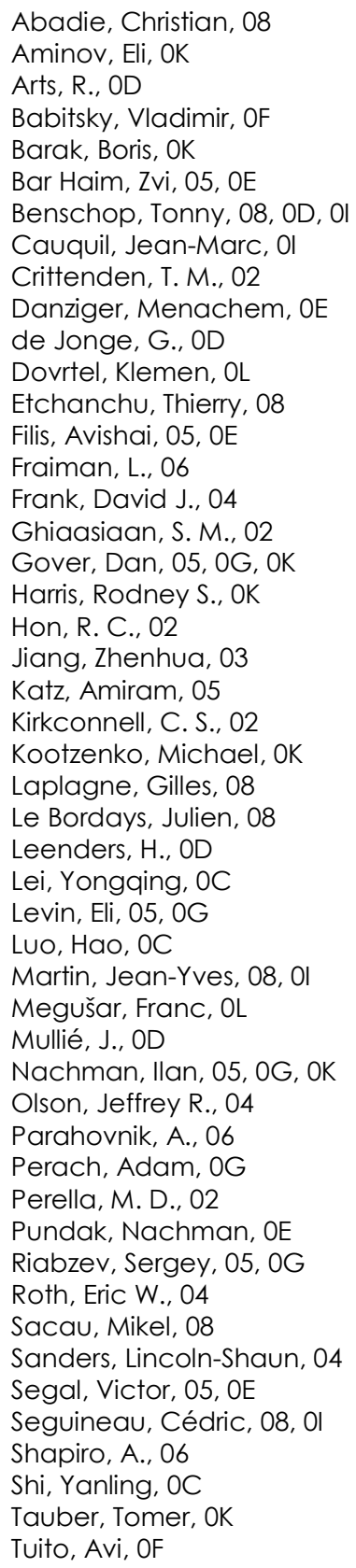

Vainshtein, Igor, OG

Van-Acker, Sébastien, 08, 0I

Vasse, Christophe, 08

Veprik, Alexander, OF

Will, Eric, 04

Wu, Yinong, 03

Yin, Jianping, 0C

Zhong, Biao, OC 
Proc. of SPIE Vol. $101801018001-6$

Downloaded From: https://www.spiedigitallibrary.org/conference-proceedings-of-spie on 25 Apr 2023 Terms of Use: https://www.spiedigitallibrary.org/terms-of-use 


\section{Conference Committee}

Symposium Chair

Donald A. Reago Jr., U.S. Army Night Vision \& Electronic Sensors

Directorate (United States)

Symposium Co-chair

Arthur A. Morrish, Raytheon Space and Airborne Systems

(United States)

Conference Chairs

Richard I. Epstein, The University of New Mexico (United States) and ThermoDynamic Films, LLC (United States)

Bjørn F. Andresen, RICOR Cryogenic \& Vacuum Systems (Israel)

Tonny Benschop, Thales Cryogenics B.V. (Netherlands)

Joseph P. Heremans, The Ohio State University (United States)

Sergey V. Riabzev, RICOR Cryogenic \& Vacuum Systems (Israel)

Mansoor Sheik-Bahae, The University of New Mexico (United States)

Conference Program Committee

Igor D. Burlakov, Orion Research-and-Production Association

(Russian Federation)

Bernardo Farfan, The University of New Mexico (United States) and ThermoDynamic Films, LLC (United States)

Markus P. Hehlen, Los Alamos National Laboratory (United States)

Carl S. Kirkconnell, West Coast Solutions (United States)

Alexander Veprik, SCD SemiConductor Devices (Israel)

Ingo N. Rühlich, AIM INFRAROT-MODULE GmbH (Germany)

Yinong Wu, Shanghai Institute of Technical Physics (China)

Session Chairs

Welcome

Sergey V. Riabzev, RICOR Cryogenic \& Vacuum Systems (Israel)

1 Mechanical Coolers: Miniaturization

Tonny Benschop, Thales Cryogenics B.V. (Netherlands)

Carl S. Kirkconnell, West Coast Solutions (United States) 
2 Emerging Technologies I

Aram Gragossian, The University of New Mexico (United States)

Matthew Grayson, Northwestern University (United States)

3 Emerging Technologies II

Matthew Grayson, Northwestern University (United States)

4 Mechanical Coolers: Design Issues

Alexander Veprik, SCD SemiConductor Devices (Israel)

Ingo N. Rühlich, AIM INFRAROT-MODULE GmbH (Germany)

5 Mechanical Coolers: Various

Yinong Wu, Shanghai Institute of Technical Physics of the Chinese Academy of Sciences (China)

Sergey V. Riabzev, RICOR Cryogenic \& Vacuum Systems (Israel) 